\title{
Challenges of School Boards in Management of Subsidized Funds for Secondary Education in Kiminini Sub-County in Kenya
}

\author{
Johnson Bulowa, Sarah Likoko \\ Department of Educational Planning and Management, Kibabii University, Kenya
}

\begin{abstract}
The study evaluated the management of funds for subsidized secondary education in public day schools in Kiminini Sub-County in Kenya. The study adopted descriptive survey design. The target population included all the Boards of Management of 68 public secondary schools in Kiminini SubCounty. Purposive sampling technique was used to select 21 head teachers from 21 sampled schools. Data was analyzed using descriptive statistics. A questionnaire was used in data collection. Correlation analysis established that challenges negatively and significantly influence effectiveness of managing funds.
\end{abstract}

Keywords: Boards of Management, Challenges, Funds, Subsidized, Secondary Education

\section{INTRODUCTION}

$\mathrm{T}$ The launching of Subsidized Day Secondary school Education by the government in 2008 was historic and intended to develop the education sector. It was an important policy by the NARC government. This led to an increase in the education budget. However, the haste in which the program was implemented left gaps such as the need for principals and members of BOM to be prepared in handling finances. The government started organizing for in- service courses for them that were equally expensive. The government had recognized that changes within the society and within the education system itself requires continuous inservice to enable staff managers acquire knowledge, skills and attitude for the roles.

The World Bank (1980) pointed out some of the repercussions for mismanagement of resources being lack of preparation for principals of schools to handle financial affairs. Following the above, the government established Kenya Education Staff Institute (KESI) to offer in-service training for the principals of secondary schools on the management of schools that included financial management (Kamunge, 1988). Lack of managerial skills among principals and BOM members has been a major challenge in the handling of subsidized funds for day secondary schools. Whenever the principal is promoted, he does not undergo training that is geared towards financial management. This is also applicable to members of BOM who serve in a school for a period of three years.

The competencies of principals to handle finances can be summed in the following statement: "too often and without consideration, principals in developing countries like Kenya are tossed into the job without pre-service training, without guarantee for in-service training, and without support from their employers. Some regrettably, find that their effectiveness and performance are judged according to how little they bother education officers, including teachers' service commission and ministry of education." Kitavi (1995). Inadequate preparation to handle funds by BOM members might lead to financial mismanagement. Some of the BOM members do not understand their role in the new policy of subsidized funds in day secondary schools. It therefore appears as if the BOM members role has been reduced to rubber stamping what had already been decided by the principal. An education management capacity assessment carried out by research, triangle institute international and the east Africa development consultants on behalf of the Ministry of Education in 2009 showed most principals of schools had no practical skills and therefore being secretary to BOM members, are unable to give them proper guidance on how to make use of subsidized funds in effective ways (Aduda, 2007).

The turnover of BOM members every after three years means a whole team can leave paving way for other members who might be totally unexposed on financial matters, thus lacking the capacity to assist the principal in the general handling of finances. As a result county auditors have been given mandate to continue advising the school managers on financial matters. The challenge on training in financial management skills stands out as a key issue Nishimuva (2008) observes that the success of Kenya's decentralized system of school financial management depends in large the capacity of school administration to manage limited resources with limited means. Cheruto (2010) reported that head teachers had cited inadequate training in financial management as contributing to lack of capacity and confidence for effective financial management. It should also be noted in this study that inservice for principals of secondary schools may not have an effect if the other members of BOM lack the requisite experience and proper qualification in management. Therefore, this study is to find out if the same challenges are manifested in the same manner in Kiminini sub-county is the general meaning of the study. 
Another challenge reported in many studies is the prevalence of corruption in the handling of subsidized funds. There are no transparent procurement guidelines for schools. Often teachers end up as suppliers fuelling conflict of interest in the handling of funds. A study by commonwealth education fund observed that the government provides national guidelines to all schools on how procurement should be done and how the process should be transparent to prevent corrupt practices but some corruption continues despite these guidelines.

The other challenge highlighted by many studies is the lack of involvement by stake holders in the management of subsidized funds for day secondary schools. The main stakeholders here are parents who believe the government is taking care, Serem and Kipkoech (2012). The lack of interest by the community is as a result of unclear policy on the role of the community in the handling of subsidized funds. Inadequate training on the part of the BOM members, by failing to audit the projects and sensitize the community on their roles to ensure success of subsidized funds for day secondary schools. Therefore, it is interesting to know how prepared are the members of BOM in the management of the schools for the success of the projects in public Day secondary schools in Kiminini Sub-County.

From the literature review, the study sought to answer the following research question;

What are the challenges encountered by the school boards in the Management of Funds for Subsidized Day Secondary Schools?

\section{RESULTS AND DISCUSSION}

\subsection{Challenges in the Managing of Funds for Subsidized Day Secondary School Education}

Key: SA-strongly agree-5, A-agree-4, N-Neutral-3, SD- strongly disagree-22, D-disagree-1

Table 1: Challenges in the Management of Funds

\begin{tabular}{|c|c|c|c|c|}
\hline Statement & $\mathrm{f}$ & $\%$ & Mean & Std \\
\hline $\begin{array}{c}\text { The government started organizing for in- } \\
\text { service courses for them that were equally } \\
\text { expensive. }\end{array}$ & 25 & 65 & 4.32 & 1.712 \\
\hline $\begin{array}{c}\text { Lack of preparation for principals of schools } \\
\text { to manage financial affairs. }\end{array}$ & 23 & 63 & 4.12 & 2.921 \\
\hline $\begin{array}{c}\text { Lack of managerial skills among principals } \\
\text { and BOM members has been a major } \\
\text { challenge. }\end{array}$ & 28 & 62 & 4.03 & 1.984 \\
\hline $\begin{array}{c}\text { Too often and without consideration, } \\
\text { principals in developing countries like } \\
\text { Kenya are tossed into the job without pre- } \\
\text { service training. }\end{array}$ & 26 & 68 & 4.34 & 0.984 \\
\hline $\begin{array}{c}\text { Lack of support to principles from their } \\
\text { employers TSC. }\end{array}$ & 23 & 63 & 4.12 & 2.00 \\
\hline $\begin{array}{c}\text { Effectiveness and performance of principles } \\
\text { are judged according to how they bother } \\
\text { education officers, including teachers' } \\
\text { service commission and ministry of } \\
\text { education. }\end{array}$ & 25 & 64 & 4.30 & 0.957 \\
\hline
\end{tabular}

\begin{tabular}{|l|l|l|l|l|}
\hline $\begin{array}{l}\text { Inadequate preparation to manage funds by } \\
\text { BOM members might lead to financial } \\
\text { mismanagement. }\end{array}$ & 25 & 55 & 4.54 & 1.871 \\
\hline $\begin{array}{l}\text { Some of the BOM members do not } \\
\text { understand their role in the new policy of } \\
\text { Subsidized Day Secondary School } \\
\text { Education. }\end{array}$ & 23 & 50 & 4.34 & 0.921 \\
\hline $\begin{array}{l}\text { The turnover of BOM members every after } \\
\text { three years means a whole team can leave } \\
\text { paving way for other members who might } \\
\text { be totally unexposed on financial matters. }\end{array}$ & 28 & 62 & 4.23 & 2.001 \\
\hline $\begin{array}{l}\text { The challenge on training in financial } \\
\text { management skills. }\end{array}$ & 26 & 58 & 1.34 & 1.984 \\
\hline $\begin{array}{l}\text { Prevalence of corruption in the managing of } \\
\text { subsidized funds. }\end{array}$ & 23 & 50 & 4.12 & 1.841 \\
\hline $\begin{array}{l}\text { No transparent procurement guidelines for } \\
\text { schools. }\end{array}$ & 25 & 55 & 4.32 & 1.342 \\
\hline $\begin{array}{l}\text { Often teachers end up as suppliers fuelling } \\
\text { conflict of interest in the managing of funds. }\end{array}$ & 25 & 55 & 4.32 & 2.612 \\
\hline $\begin{array}{l}\text { The lack of involvement by stake holders in } \\
\text { the management of subsidized funds. }\end{array}$ & 23 & 50 & 4.12 & 1.421 \\
\hline The lack of interest by the community. & 28 & 62 & 4.03 & 0.984 \\
\hline $\begin{array}{l}\text { Unclear policy on the role of the community } \\
\text { in the management of Subsidized Day } \\
\text { Secondary School Education. }\end{array}$ & 26 & 58 & 4.34 & 2.984 \\
\hline $\begin{array}{l}\text { BOM members failing to audit the projects } \\
\text { and sensitize the community on their roles. }\end{array}$ & 23 & 50 & 4.12 & 1.876 \\
\hline
\end{tabular}

The results in the table 1 above show that the respondents agree (mean of 4.000) that the government started organizing for in- service courses for them that were equally expensive. They agree that lack of preparation for principals of schools to manage financial affairs, lack of managerial skills among principals and BOM members has been a major challenge, too often and without consideration, principals in developing countries like Kenya are tossed into the job without preservice training, Lack of support to principles from their employers TSC. They agree that effectiveness and performance of principles are judged according to how they bother education officers, including teachers' service commission and ministry of education. They agree that inadequate preparation to manage funds by BOM members might lead to financial mismanagement, Some of the BOM members do not understand their role in the new policy of Subsidized Day Secondary School Education and the turnover of BOM members every after three years means a whole team can leave paving way for other members who might be totally unexposed on financial matters. The respondents agree that the challenge on training in financial management skills, prevalence of corruption in the managing of subsidized funds and there are no transparent procurement guidelines for schools. They also agree that often teachers end up as suppliers fuelling conflict of interest in the managing of funds, the lack of involvement by stake holders in the management of funds meant for the programme, there is lack of interest by the community. There are unclear policies on the role of the community in the management of funds meant for Subsidized Day Secondary School Education and BOM members failing 
to audit the projects and sensitize the community on their roles.

Table 2: Chi-Square Tests for challenges in the management of funds

\begin{tabular}{|c|c|c|c|}
\hline \multicolumn{5}{|c|}{ Chi-Square Tests } \\
\hline & Value & df & Asymp. Sig. (2-sided) \\
\hline $\begin{array}{c}\text { Pearson Chi- } \\
\text { Square }\end{array}$ & $41.521^{\mathrm{a}}$ & 27 & .000 \\
\hline $\begin{array}{c}\text { Likelihood Ratio } \\
43.818\end{array}$ & 27 & .000 \\
\hline $\begin{array}{c}\text { Linear-by-Linear } \\
\text { Association }\end{array}$ & 21.384 & 1 & .000 \\
\hline N of Valid Cases & 45 & & \\
\hline \multicolumn{5}{|c|}{$\begin{array}{c}\text { a. 23 cells (57.5\%) have expected count less than 5. The minimum } \\
\text { expected count is 22. }\end{array}$} \\
\hline
\end{tabular}

In table 2 above, the significance value is so low that it is displayed as .000 , which means that it would appear that challenges and effective funds management are, indeed, related.

Table 3: Correlation between Challenges in the Management of Funds for Subsidized Day Secondary School Education

\begin{tabular}{|c|c|c|}
\hline \multicolumn{2}{|c|}{} & $\begin{array}{c}\text { Effective management of } \\
\text { funds }\end{array}$ \\
\hline \multirow{3}{*}{ Challenges } & Pearson Correlation & $-.390^{*}$ \\
\cline { 2 - 3 } & Sig. (2-tailed) & .027 \\
\cline { 2 - 3 } & N & 45 \\
\hline
\end{tabular}

**. Correlation is significant at the 0.01 level (2-tailed).

Table 3 above show that challenges negatively and significantly influence effectiveness of managing funds at $r=-$ $.390^{* *}, \mathrm{p}<0.05$. Calculating the coefficient of determinant $\mathrm{R}$, status of subsidized projects contributes $15.21 \%$ variability to effective of managing funds when other factors are held constant.

The results in Table 1 indicate that the government started organizing for in- service courses for them that were equally expensive. The responses indicated that there was inadequate preparation for principals of schools to manage financial affairs, inadequate managerial skills among the BOM members, inadequate support to Principals from their employers TSC.

Further, the results established that there was inadequate preparation to manage funds by BOM members might lead to financial mismanagement. Implying that some of the BOM members had little understanding of their roles. Moreover, the study established the following; the challenge on training in financial management skills, prevalence of corruption in the managing of subsidized funds and lack of transparency in procurement procedures.

Chi-squire analysis revealed that there was a relationship between challenges and effective funds management.

Further correlation analysis established that challenges negatively and significantly influence effectiveness of managing funds contributing $15.21 \%$ variability to effective of managing funds when other factors are held constant.

The findings in Table 3, agree with those of Cheruto and Kyalo(2010) who observed that inadequate training in financial management contribute to lack of capacity and confidence for effective financial management in schools. However, generalizability of the findings was limited as Cheruto and Kyalo (2010) focused on primary school management. Therefore, the current sought to fill the gap by investigating the challenges of secondary school Boards in financial management.

\section{CONCLUSION}

Based on the findings, the study concludes that challenges that significantly influence effectiveness management of school funds by the boards includes; inadequate knowledge in financial management and corruption practices.

\section{RECOMMENDATION}

The study made the following recommendations;

- The government to establish ways of enforcing national guidelines to all schools on procurement procedures to minimize corrupt practices.

- School Boards of management should be well equipped with knowledge and skills in financial management so as to be able to give proper guidance on how to make use of subsidized funds in effective ways.

\section{REFERENCES}

[1] Aduda, D. (2007, July 7th). "Power to School Boards." Nairobi: Daily Nation. Nation Media Group.

[2] Cheruto, K.L., \& Kyalo, W. B. (2010). Managementchallenges facing implementation of free primary education in Kenya: A case of Keiyo District. Journal of Education Administration and Policy Studies Vol.2(5), pp. 71-76, June 2010

[3] Serem, D.K., \&Kipkoech, L. C. E. (2012).Role of Community in the Management of Free Primary Education in Kenya. Kenyatta University, Kenya. https://www.questia.com/library/journal/1P33086871781/role-of Community-in-the- management-of-freeprimary 